\title{
EVALUATION OF THE EFFICACY OF LOW-LEVEL LASER THERAPY (LLLT) AND THE MICROELECTRIC NEUROSTIMULATION (MENS) IN THE TREATMENT OF MYOGENIC TEMPOROMANDIBULAR DISORDERS: A RANDOMIZED CLINICAL TRIAL
}

\author{
AVALIAÇÃO DA EFICÁCIA DO LASER DE BAIXA FREQÜÊNCIA E DO \\ NEUROESTÍMULO MICRO ELÉTRICO (MENS) NO TRATAMENTO DAS DISFUNÇÕES \\ TEMPOROMANDIBULARES MIOGÊNICAS: UM ESTUDO CLÍNICO RANDOMIZADO
}

Evelyn Mikaela KOGAWA ${ }^{1}$, Melissa Thiemi KATO ${ }^{2}$, Carlos Neanes SANTOS ${ }^{3}$, Paulo César Rodrigues CONTI ${ }^{4}$

\begin{abstract}
1- DDS, MSc, Graduate student (Master degree), Prosthodontics Department, Bauru Dental School - University of São Paulo. 2- DDS, MSc, Graduate student (Master degree), Public Health Department, Bauru Dental School - University of São Paulo.

3- DDS, MSc, PhD, Graduate Student (Doctor Degree), Prosthodontics Department, Bauru Dental School - University of São Paulo.

4- DDS, PhD, Associate Professor, Prosthodontics Department, Bauru Dental School - University of São Paulo.

Corresponding address: Evelyn Mikaela Kogawa - Al. Octávio Pinheiro Brisolla 9-75 - Departamento de Prótese - Vila Universitária Cep.: 17012-901 - Bauru-SP Brasil - Fone: (14) 3235-8340 - e-mail: evelyn_mikaela@yahoo.com.br
\end{abstract}

Received: October 26, 2004 - Modification: December 3, 2004 - Accepted: June 29, 2005

\begin{abstract}
$\mathrm{O}$ bjective: The aim of the present study was to evaluate the efficacy of low-level laser therapy (LLLT) and the microelectric neurostimulation (MENS) in the treatment of patients with temporomandibular disorders (TMD). Material and methods: A sample of 19 individuals presenting with signs and symptoms of myogenic TMD was randomly divided into two groups (I - LLLT and II - MENS). Therapy was done in 10 sessions, three times a week, for one month. Patients were evaluated by the Visual Analogue Scale (VAS), measurement of active range of motion (AROM) and muscle palpation, performed immediately before and 5 minutes after each therapeutic session by a blinded TMD specialist. The ANOVA for repeated measurements and Mann-Whitney tests were used for the statistical analysis. Results: The results showed an increase in maximum mouth opening and a decrease in tenderness to palpation for both groups. The VAS reduced for both groups, although more evident for the laser group $(\mathrm{p}<0.05)$. Conclusion: Authors concluded that both therapies were effective as part of the TMD treatment, and the cumulative effect may have been responsible for this fact. However, caution is recommended when judging the results due to the self-limiting aspect of musculoskeletal conditions such as TMD.

Uniterms: Low-level laser therapy (LLLT); Temporomandibular joint disorders; Randomized controlled trials; Microelectric neurostimulation.
\end{abstract}

\section{RESUMO}

$\mathrm{O}$ jetivo: Avaliar a efetividade do laser de baixa freqüência e do estímulo muscular microelétrico (MENS) no tratamento de pacientes com disfunções temporomandibulares (DTM). Material e Métodos: Uma amostra de 19 indivíduos com sinais e sintomas de DTM de origem muscular, foi dividida em dois grupos (I -laser e II - MENS). O tratamento consistiu de 10 sessões, três vezes por semana, durante um mês. Os critérios de avaliação dos pacientes foram: escala de análise visual (EAV), mensuração de abertura máxima bucal e palpação muscular, estes foram avaliados imediatamente antes e 5 minutos após cada sessão terapêutica, num estudo do tipo controlado. Para análise estatística, foram aplicados ANOVA para mensurações repetidas e Mann-Whitney. Resultados: Os resultados demonstraram aumento da abertura bucal máxima e diminuição na sensibilidade à palpação em ambos os grupos e, em relação à EAV, ambos os grupos demonstraram decréscimo, mas houve uma diferença estatisticamente significante entre os grupos, já que o grupo laser apresentou os melhores resultados $p<0,05$. Conclusão: Os autores concluíram que as duas terapias foram efetivas como parte do tratamento das DTM, e o efeito cumulativo podem ter sido responsável pela melhora. Porém sugere-se cautela quando se analisam os resultados devido ao aspecto autolimitante das condições músculoesqueletais como as DTM.

Unitermos: Terapia a laser de baixa intensidade; Transtornos da articulação temporomandibular; Ensaios controlados aleatórios. 


\section{INTRODUCTION}

Combined therapies have been proposed in the management of symptoms of TMD. This interdisciplinary approach is necessary because of the multifactorial aspect of these problems. Different forms of treatments other than the historical occlusal are part of the global management and are known as supportive therapy ${ }^{27}$.

According to Ogus and Tooller ${ }^{26}$ (1986) and Guralnick ${ }^{16}$ (1984), TMD management is more effective when patient is treated according to a logical sequence of importance, i.e.: treatment of the symptoms, of the underlying cause, of the predisposing factors, and eventually treatment of the pathological effects. Physical therapy has been used for many years as a support therapy. To increase patient's awareness of the cause of symptoms, to achieve muscle relaxation, to reduce muscle hyperactivity, reestablishing joint movement, to relieve pain, and to allow a normal function are common physical therapy goals and objectives. Microcurrent therapy (MENS) and soft laser are some of these modalities.

Different theories are know to explain the mechanism of action of microcurrent therapy: 1) It provides ATP (adenosine triphosphate) to the cells, which is very important due to its participation in the mechanisms of contraction and relaxation of the muscle tissue, as well as for protein synthesis and cell reproduction ${ }^{4}$. 2) Application of low-frequency currents is biologically compatible with the physiological currents penetrating the cell, providing an electrochemical balance and restoring the electrophysiological state of the traumatized cell. In response to that, a decreased nociceptive message reaches the Central Nervous System (CNS), altering the painful sensation. This modality has been indicated in the treatment of myogenic pain, Temporomandibular Joint (TMJ) Disorders, edema reduction, etc.

On the other hand, low-level laser therapy (LLLT) has analgesic, antiedematous and biostimulating effects $^{12,18,19,23,28,29}$. The most common types are the heliumneon laser (He-Ne gas) and the infrared laser with diode of gallium-arsenium(Ga-As) or gallium-aluminum-arsenium (GaAl-As).

Literature has recommended the use of these modalities as supportive for TMD treatment. Bertolucci and Grey $^{2}$ (1995) compared the effect of MENS, Mid-laser and placebo in the treatment of patients with pain associated to active joint dysfunction of the TMJ. Authors observed that the MENS and Mid-laser were effective for reducing pain and improving mandibular movement. Mid-laser was superior to MENS concerning application and effect, and both were significantly better than the placebo treatment. Du Pont Jr' in 1999, described a protocol for the use of microcurrent in the identification of trigger points and treatment of myofascial pain.

Macedo and Mello ${ }^{22}$ (2002) evaluated the efficacy of the hydrostatic splint Aqualizer ${ }^{\mathrm{TM}}$, MENS and TENS (transcutaneous electrical neural stimulation) therapies in patients with TMD in acute situations and concluded that the MENS and the hydrostatic splint were more effective than TENS. In the same year, Guimarães, et al. ${ }^{15}$, in a pilot study, evaluated the clinical efficacy of electrotherapy employing TENS and MENS in a sample of 14 patients. Authors reported significant improvements when MENS therapy was used. Bezuur, Habets, Hansson ${ }^{3}$ (1988), found that the low-level laser therapy (LLLT) was effective after a short period of treatment and was still stable after one-year follow-up for patients with arthrogenic TMD. Conti ${ }^{5}$ (1997), evaluated the efficacy of the low-level laser therapy in TMD by means of a double-blind placebo controlled study. The author observed an improvement of pain report for patients with myogenic pain, while improved mandibular movement was found for arthrogenic patients.

Beckerman, et al. ${ }^{1}$ (1992), studied the efficacy of laser therapy in musculoskeletal disorders in a meta-analysis and concluded that the treatment with low-level laser provided more reliable results for pain treatment in double blind protocols. In a similar publication, however, Gam, Thorsen and Lonnberg ${ }^{11}$ (1993), concluded that the low-level laser therapy is not effective for musculoskeletal disorders. Tullberg, Alstergren and Enberg ${ }^{32}$ (2003) also reported that the pain intensity was not affected by the laser exposure, while Kitchen and Partridge ${ }^{21}$ (1991) were unable to draw conclusions, because the results differed greatly between trials, as did the types of lasers used and the doses.

Therefore, the aim of this study is to evaluate the efficacy of low-level laser therapy (LLLT) and microcurrent therapy (MENS) in the treatment of myogenic TMD patients.

\section{MATERIALAND METHODS}

A sample of 19 women (mean age 26.4 years) was selected among those attending the Orofacial Pain Center of the Department of Prosthodontics, Bauru Dental School (University of São Paulo), Brazil.

The entire sample was informed on the objectives of the study and an informed consent term, in agreement with the Regulation \#196/96 of the Brazilian National Health Council, was signed.

Initial clinical examination included anamnesis and detailed physical inspection, comprising muscle and TMJ palpation, evaluation of the mandibular movement and joint sounds. Inclusion criteria was the presence of myofascial pain, according to the Research Diagnostic Criteria for $\mathrm{TMD}^{7}$ and tenderness to palpation in the masseter or anterior temporalis.

Patients with TMJ pain, systemic diseases (e.g. rheumatoid arthritis, fibromyalgia) ${ }^{5,32}$, previous treatment for TMD, occlusal factors of risk, toothache, neuralgia or local skin infection over the most tender spot of the masseter and temporal muscles were excluded. The presence of major psychological disturbances and restriction for the use of LASER and MENS (e.g. pacemaker users) were also exclusion criteria.

After initial evaluation and diagnosis, each patient was randomly assigned either to group I (LLLT) (9 patients) or group II (MENS), with 10 individuals. A research assistant 
carried out the selection of the patients in order to establish a double-blind design. Randomization was done with the help of a computer generated sequence of distribution. In order to better distribute the sample as for VAS levels, a stratification method was used during the randomization process. After that similar levels for both groups were obtained $(4.4 \mathrm{~mm}$ and $6.0 \mathrm{~mm}$ for MENS and Laser, respectively). A wash-out period (3 days without medication) was requested to all participants before beginning of the trial ${ }^{14}$. During the course of this study, patients were also requested not to take analgesic drugs or to have any other form of therapy.

Laser therapy was performed 3 times a week, in a total of ten sessions, using a low-level laser device of Ga-Al-As with wavelength of 830 to $904 \mathrm{~nm}$, with an output of 4 joules per $\mathrm{cm}^{2}$ and power of 100mW (VR-KC-610 SOFT LASER Dentoflex, São Paulo-SP, Brazil).

Microcurrent therapy was also performed 3 times a week, in a total of ten sessions, employing a MIOSOFT MILLENNIUM MTC \#17849 apparatus (DENTOFLEX, São Paulo - SP, Brazil). Application was done for 20 minutes, and the current frequency ranged from 40 to $160 \mathrm{~mA}$.

The main researcher applied the laser therapy, while MENS was applied by a general practitioner. Moreover, a TMD specialist conducted the physical evaluation of the patients before and after each session. Each patient was evaluated immediately before and five minutes after each session, when the active mouth opening, TMJ and muscle palpation, and Visual Analogue Scale (VAS) were evaluated.

The VAS is a measurement of pain, in which all individuals scored their pain on a horizontal line measuring $100 \mathrm{~mm}$, where the left end means "no pain" and the right end indicates "the worst pain imaginable".

With the RDC as a guide ${ }^{7}$, the muscle palpation was performed bilaterally, with approximately $1.5 \mathrm{kgf}$ of pressure, and it was graded from zero to three, depending on the patient's reaction to palpation.

The Student's “t” test was used for intragroup analysis and the three-way ANOVA for repeated measurements evaluated differences between groups (LASER X MIOSOFT), differences before and after each therapy session (immediate effect) and differences between sessions. The Mann-Whitney test was also used for intragroup evaluation for tenderness to palpation. A significance level of $5 \%$ was adopted.

\section{RESULTS}

\section{Visual Analogue Scale (VAS)}

The initial mean VAS for the laser (LLLT) and MENS groups were $66.1 \mathrm{~mm}$ and $44 \mathrm{~mm}$, respectively. Final figures were $4.4 \mathrm{~mm}$ and $6 \mathrm{~mm}$, respectively.

When within groups analysis was performed, both groups had significant improvements for both VAS and muscle palpation analysis $(\mathrm{p}<0.01)$. The laser group demonstrated a more significant pain reduction (VAS) when between groups analysis was done $(\mathrm{p}=0.01)$

The progress of the treatment may be visualized in Figure 1 , where an improvement before and after each session is observed.

\section{Active range of motion (AROM)}

Figure 2 shows the maximal opening mean values for both experimental groups during the treatment period. The initial and final means of maximum opening for the LASER group were $43 \mathrm{~mm}$ and $47.6 \mathrm{~mm}$, respectively; while for the MENS group were $46.3 \mathrm{~mm}$ and $49.4 \mathrm{~mm}$. No significant difference was found ( $\mathrm{p}>0.05)$ between groups.

\section{Muscle palpation}

No significant difference between groups for muscle palpation for both groups were found at both sides ( $p>0.05$ ).

Variation of the pain condition for the anterior temporalis and masseter at the right and left sides are seen in Figures 3, 4,5 and 6 , respectively.

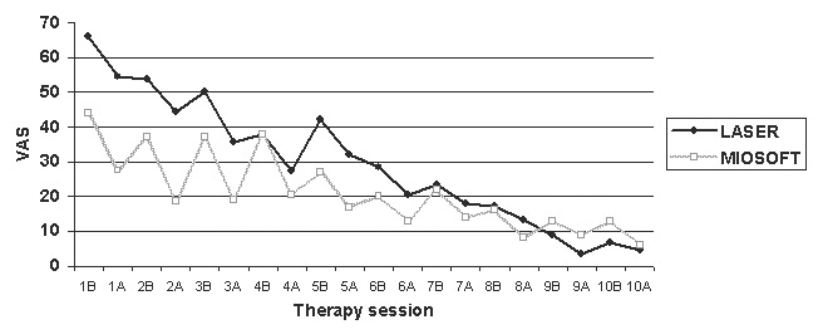

FIGURE 1- Visual Analogue Scale for each study group, before and after each therapy session

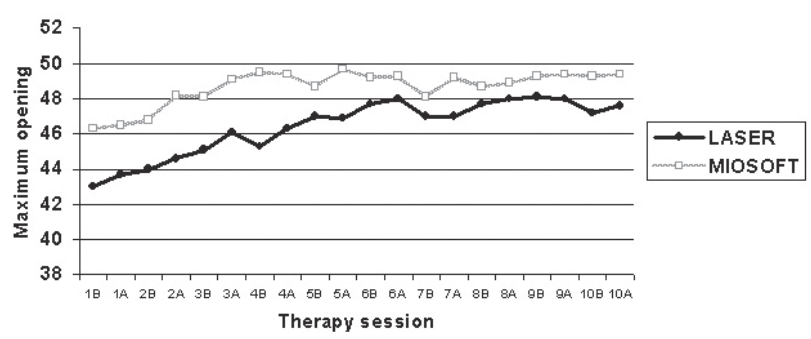

FIGURE 2- Mean maximum opening in millimeters for each group, before and after each therapy session

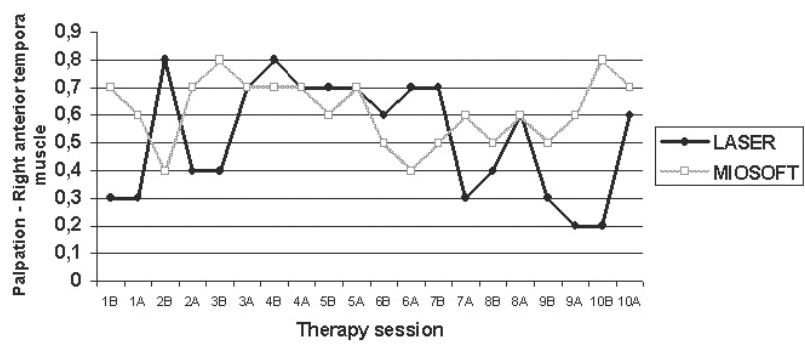

FIGURE 3- Mean palpation figures (from 0 to 3 ) of the right anterior temporal muscle, before and after each therapy session 


\section{DISCUSSION}

The results of this study demonstrated a drop of the pain report for both groups, when VAS was used. When intragroup analysis is considered, however, the laser group had a better outcome when compared to the MENS group, in agreement with Bertolucci, et.al. ${ }^{2}(1995)$. This fact should be interpreted with caution, since the whole sample has reported a significant improvement in the final assessment. Another issue to be considered is the different initial mean VAS between groups (probably due to randomization), which certainly influenced the final difference between both modalities. When comparing the VAS reduction for both groups, very similar figures are found ( $86 \%$ and $87 \%$ for LLT and MENS groups, respectively).

Tenderness to muscle palpation has also decreased for the whole sample, regardless of the group distribution. Although not a true object finding, muscle palpation can be result of a local tissue healing, consequence of both therapies. It has been proposed that muscle pain occurs due to hypoxia and energy deficit, then the better response to muscle palpation could be due to stimulation of muscle blood circulation. Tullberg, Alstergren and Enberg ${ }^{32}$,

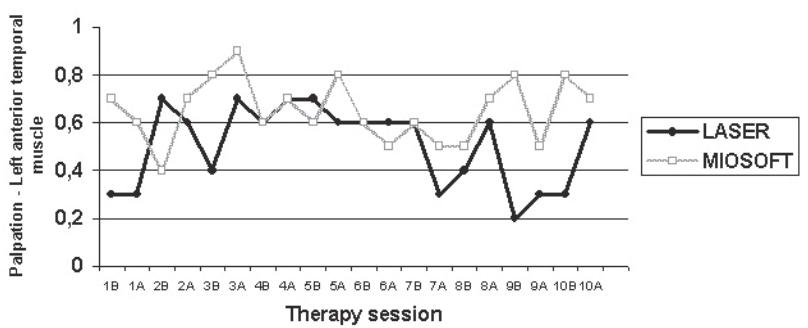

FIGURE 4- Mean palpation figures (from 0 to 3 ) of the left anterior temporal muscle, before and after each therapy session

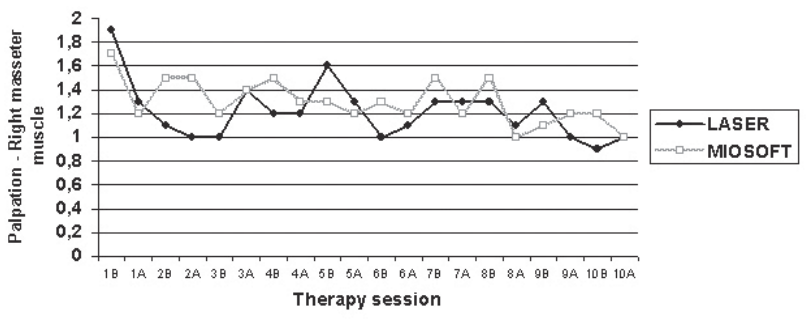

FIGURE 5- Mean of palpation figures of the right masseter muscle, before and after each therapy session

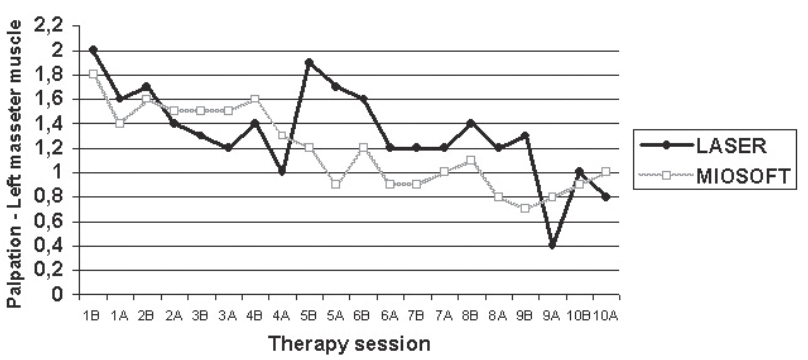

FIGURE 6- Mean of palpation figures of the left masseter muscle, before and after each therapy session however, did not find any microcirculation change in the masseter muscle, after the use of low-level laser therapy.

It is widely accepted that TMD symptoms are fluctuating and self-limiting ${ }^{27}$. It means that many patients will exhibit a natural and expected improvement, even if no therapy is offered. This fact also should be considered when interpreting the actual findings, since a placebo group was not used as control, which is a limitation of the present study. Some authors ${ }^{11,20,33,34}$ have reported good results for placebo control groups when compared to "real" electrotherapy. Feine and Lund ${ }^{8}$ (1997), after a critical analysis of review articles about the efficacy of physical therapy for the control of chronic musculoskeletal pain, concluded that patients are helped during the period that they are being treated with most forms of physical therapy, however, most of these therapies have not been shown to be more efficacious than placebo.

This is especially important in the field of chronic diseases, as TMD, where even the initial contact between patients and professionals can account for significant improvements. In spite of these facts, the great advantages of the techniques investigated are the non-invasive and reversible features. Feine, Widmer and Lund ${ }^{9}$ (1997) reported that these forms of reversible, noninvasive therapy are better than no therapy, perhaps because patients do best when clinicians take the time to fully inform them about their condition and allay their fears.

It has also been reported that electrotherapy has few side effects and is easy to apply ${ }^{2,13}$.

The use of laser as a modality of TMD treatment presents several advantages, since it induces healing and allows for tissue reorganization ${ }^{18,19,21}$. Besides, it provides fast response, is user-friendly and may be employed for both acute and chronic pain ${ }^{31}$. Wilder-Smith ${ }^{34}$ (1988), OkyayuzBaklouti $^{28}$ (1989) and Hansen and Thoroe ${ }^{17}$ (1990) report that the low-level laser provides beneficial cellular effects, such as vasodilatation, edema reduction and stimulation of healing.

Kitchen and Partridge ${ }^{21}$ (1991) also reported that the lowlevel laser promotes cell alteration and proliferation, phagocytosis and increased immune response. They also stated that healing occurs by stimulation of macrophages, mast cells degranulation, activation of fibroblasts, alteration of cell membrane, angiogenesis and photodissociation of oxyhemoglobins.

Macedo and Mello $^{22}$ (2002) reported that $40 \%$ of patients reported total remission of pain, after MENS therapy. Bertolucci and Grey $^{2}$ (1995) also found this therapy to be superior to the placebo treatment in patients with degenerative joint disease of the TMJ. Guimarães, et al. ${ }^{15}$ (2002) carried out an evaluation of MENS in 9 patients suffering from TMD, observing a significant improvement in acute cases. Also a higher rate of success of such therapies may be reached when employing MENS combined exercises.

The type of TMD should be carefully evaluated when conclusions are drawn, since the outcomes may diverge, depending on the characteristics of pain, either of muscular 
or articular origin. Conti ${ }^{5}$ (1997), has found that laser therapy improved only the mandibular movements in patients with arthrogenic dysfunction, whereas it decreased the pain in patients with myogenic disorder. On the other hand, Bezuur, Habets and Hansson ${ }^{3}$ (1988) observed a pain relief in 36\% of myogenic patients, and up to $80 \%$ the patients with arthrogenic pain.

The mandibular opening usually ranges from 53 to $58 \mathrm{~mm}$, is smaller in women than in men ${ }^{10,24,30}$ and decreases with age. It is considered limited if below $40 \mathrm{~mm}$, including the overbite $^{7,27}$. In the present study, the initial mean maximum mouth opening of the whole sample was $44.65 \mathrm{~mm}$ and the final mean, after the ten sessions of therapy, was $48.5 \mathrm{~mm}$. Obviously, the mouth opening restriction was not the primary complaint of the sample, but the improvement in this feature can be understood as a secondary effect of pain reduction, result of LASER and MENS therapy. This fact is in agreement with previous studies, when conservative methods were tested ${ }^{7,25}$.

\section{CONCLUSIONS}

1. Both therapies (LLLT and MENS) were effective in the management of myogenic TMD, but caution is recommended when analyzing such results, due to the selflimiting aspect of the TMD.

2. Active mouth opening and muscle tenderness to palpation have improved for both groups.

3. Longitudinal and controlled studies are necessary to evaluate the real effect of physical therapy modalities on TMD signs and symptoms.

\section{REFERENCES}

1- Beckerman H, Bie RA, Bouter LM, Cuyper HJ, Oostendorp RAB. The efficacy of laser therapy for musculoskeletal and skin disorders: a criteria-based meta-analysis of randomized clinical trials. Phys Ther. 1992;72(7):483-91.

2- Bertolucci LE, Grey T. Clinical comparative study of microcurrent electrical stimulation to mid-laser and placebo treatment in degenerative joint disease of temporomandibular joint. J Craniomandibular Pract. 1995;13:116-20.

3- Bezuur NJ, Habets LLMH, Hansson TL. The effect of therapeutic laser treatment on patients with craniomandibular disorders. J Craniomandibular Pract. 1988;2:83-6.

4- Cheng N. The effect of electric currents on ATP generation, protein synthesis, and membrane transport in rat skin. Clin Orthop. 1982;171:264-72.

5- Conti PCR. Low level laser therapy in the treatment of temporomandibular disorders (TMD): A double-blind pilot study. J Craniomandibular Pract. 1997;15(2):144-9.

6- DuPont JS Jr. Trigger point identificattion and treatment with microcurrent. J Craniomandibular Pract.1999;17(4):293-6.

7- Dworkin SF, LeRresche L. Research diagnostic criteria for temporomandibular disorders: review, criteria, examinations and specifications, critique. J Craniomandib Disord. 1992;6:301-55.
8- Feine JS, Lund JP. An assessment of the efficacy of physical therapy and physical modalities for the control of chronic musculoskeletal pain. Pain. 1997;71:5-23.

9- Feine JS, Widmer CG, Lund JP. Physical therapy: a critique. Oral Surg Oral Med Oral Pathol Oral Radiol Endod. 1997;83:123-7.

10- Friedman MH. Closed lock. A survey of 400 cases. Oral Surg Oral Med Oral Pathol. 1993;75(4):422-7.

11- Gam NA, Thorsen J, Lonnberg F. The effect of low-level laser therapy on musculoskeletal pain: a meta-analysis. Pain. 1993;52:636.

12- Gray RJM, Quayle AA, Hall CA, Schofield M. A temporomandibular pain dysfunction: can electrotherapy help? Physioterapy. 1995;81:47-51.

13- Gray RJM, Quayle AA, Hall CA, Schofield MA. Physiotherapy in the treatment of temporomandibular joint disorders: a comparative study of four treatment methods. Br Dent J. 1994;176:257-61.

14- Grossi ML, Goldberg MB, Locker D, Tenenbaum HC. Reduced neuropsychologic measures as predictors of treatment outcome in patients with Temporomandibular Disorders. J Orofac Pain. 2001;15(4):329-39.

15- Guimarães JP, Resende JC, Rodrigues MF. Estudo clínico da eficácia da estimulação neural elétrica transcutânea (TENS) e microcorrente elétrica (MET) no alívio sintomatológico das desordens tempormandibulares - projeto piloto. Rev Serviço ATM. 2002;2(2):29-37.

16- Guralnik W. The temporomandibular joint: The dentist's dilemma: parts I and II. Br Dent J. 1984;156:315-9, 353-6.

17- Hanssen HJ, Thoroe U. Low power laser biostimulation of chronic orofacial pain. A double-blind placebo controlled cross-over study in 40 patients. Pain. 1990;43:169-79.

18-Hansson TL. Infrared laser in the treatment of craniomandibular disorders, arthrogenous pain. J Prosthet Dent. 1989;61(5):614-7.

19- Hatano Y. Laser in the diagnosis of the TMJ problems. Laser in dentistry. 1999;1:169-72.

20- Heussler JK, Hinchey G, Margiotta E, Quinn R, Butler P, Martin $\mathrm{J}$, et al. A double blind randomised trial of low power laser treatment in rheumatoid arthritis. Ann Rheum Dis. 1993;52:703-6.

21- Kitchen SS, Partridge CJ. A review of low level laser therapy. Physiotherapy. 1991;77:161-8.

22- Macedo JF, Mello EB. Terapêuticas de urgência em desordens temporomandibulares. Rev Serviço ATM. 2002;2(2):22-8.

23- Medeiros JS. O efeito da apliacação do laser no músculo masseter sobre a força de mordida, como auxílio na terapêutica da dor orofacial [Tese de Doutorado]. São Paulo: Faculdade de Odontologia da USP; 2000.

24- Mezitis M, Rallis G, Zachariades N. The normal range of mouth opening. J Oral Maxillofac Surg. 1989;47:1028-9.

25- Monginl F, Ibertis F, Manfredi A. Long-term results in patients with disk displacement without reduction treated conservatively. Cranio. 1996;14(4):301-5.

26- Ogus HD, Toller PA. Common disorders of the temporomandibular joint. Dental Practitioner Handibook, 26. Bristol: John Wright \& Son; 1986. 
27- Okeson JP. Fundamentos de oclusão e desordens temporomandibulares. 2 ed. Artes Médicas; 1992. p.117-246.

28- Okyayuz-Baklouti I. The effects of torbafyline on blood flow, and function of rat ischaemic skeletal muscle. Eur J Pharmacol.1989;166(1):75-86.

29- Palano D, Martelli M, Avi R, Gaurneri L, Palmieri B. A clinicostatistical investigation of laser effect in the treatment of pain and dysfunction of temporomandibular joint (TMJ). Medical Laser Report. 1985;(2):21-9.

30- Szentpetery A . Clinical utility of mandibular movement ranges. J Orofac Pain. 1993;7:163-8.

31- Thomasson TL. Effects on skin-contact monochromatic infrared irradiation on tendonitis, capsulitis and myofascial pain. J Neuro \& Orthop Med Surg. 1996;16(4):242-5.

32- Tullberg M, Alstergren PJ, Enberg MM. Effects of low-power laser exposure on masseter muscle pain and microcirculation. Pain. 2003;105:89-96.

33- Waylonis GW, Wilke S, Toole DO, Waylonis DA, Waylonis DB. Chronic myofascial pain: management by low-output helium-neon laser therapy. Arch Phys Med Rehabil. 1988,69:1017-20.

34- Wilder-Smith P. The soft laser: therapeutic tool or popular placebo? Oral Surg Oral Med Oral Pathol. 1988;66(6):654-8. 